\title{
Proline as a probable biomarker of cold stress tolerance in Sorghum (Sorghum bicolor)
}

\section{Prolina como probable biomarcador de tolerancia a estrés por frío en Sorgo (Sorghum bicolor)}

Pedro Vera-Hernández, Marco Antonio Ortega Ramírez, Marcelino Martínez Núñez, Magali Ruiz-Rivas, Flor de Fátima Rosas-Cárdenas*

Centro de Investigación en Biotecnología Aplicada-IPN, Ex-Hacienda San Juan Molino Carretera Estatal Tecuexcomac-Tepetitla Km 1.5, Tlaxcala C.P. 90700, México.

*Corresponding author.

E-mail address: frosasc@ipn.mx (F. F. Rosas-Cárdenas).

Article history:

Received: 18 December 2017 / Received in revised form: 4 April 2018 / Accepted: 4 May 2018 / Published online: 1 July 2018.

https://doi.org/10.29267/mxjb.2018.3.3.77

\begin{abstract}
Plants have developed physiological and molecular mechanisms to support and adapt to adverse environments. One response to abiotic stress is the accumulation of free proline (PRO). PRO can induce the expression of many genes, which have the proline-responsive element (PRE) in their promoters, nevertheless due to the complexity of interactions between stress factors and various molecular, biochemical and physiological phenomena it is still unclear whether a more efficient PRO accumulation can be considered a biomarker of tolerance in plants. In the present work, we evaluated the accumulation of PRO in two genotypes of sorghum with contrasting tolerance to cold stress. To explore the cause behind the accumulation of proline under cold stress conditions, we identified the Transcription Factors Binding Sites (TFBS) present in the promoter regions in the genes involved in the biosynthesis and degradation of proline in sorghum and other important crops, finding that the untranslated 3 'region P5CS gene contains different TFBS. We found TFBS that could allow the activation of genes involved in proline biosynthesis through the ornithine pathway under cold stress conditions, suggesting that ornithine route can be activated under cold stress conditions.
\end{abstract}

Keywords: Biomarker, Cold, Proline, Sorghum, TFBS. 


\section{RESUMEN}

Las plantas han desarrollado mecanismos fisiológicos y moleculares para soportar y adaptarse a entornos adversos. Una de las respuestas a condiciones de estrés abiótico es la acumulación de prolina (PRO). PRO puede inducir la expresión de distintos genes, que tienen el elemento de respuesta a prolina (PRE) en sus promotores, sin embargo, debido a la complejidad de las interacciones entre los factores de estrés y varios fenómenos moleculares, bioquímicos y fisiológicos aún no está claro si la acumulación de PRO puede considerarse un biomarcador de tolerancia en las plantas. En el presente trabajo evaluamos la acumulación de PRO en dos genotipos de sorgo con tolerancia contrastante a estrés por frío. Para explorar la causa detrás de la acumulación de prolina ante condiciones de estrés por frío, identificamos los TFBS presentes en las regiones promotoras en los genes involucrados en la biosíntesis y degradación de prolina en sorgo y otros cultivos importantes encontrando que la región 3' no transcrita del gen P5CS contiene diferentes TFBS. Encontramos TFBS que pudieran permitir la activación de los genes involucrados en la biosíntesis de prolina a través de la vía de ornitina ante condiciones de estrés por frío lo que sugiere que dicha vía puede activarse ante condiciones de estrés por frío.

Palabras clave: Biomarcador, Frío, Prolina, Sorgo, TFBS.

\section{INTRODUCTION}

Sorghum is a crop adapted mainly to warm areas. However, a minimum amount of sorghum has been grown in the colder highlands. These sorghums are cold tolerant and can grow on the high ground less suitable for sorghum cultivation. The term "cold tolerance" is used to describe the ability of sorghum genotypes to germinate, grow and produce seed satisfactorily under conditions of low temperatures, but above freezing (Singh, 1985). When susceptible sorghums are cultivated in cold conditions one or more of the following features happens: reduced, or no germination (Tiryaki \& Andrews, 2001), the predisposition of sorghum to diseases (McLaren \& Wehner, 1992), and female or male sterility which leads to decreased seed production (Downes \& Marshall, 1971). Sorghum responds to adverse conditions with a series of morphological, physiological, biochemical and molecular changes, regulated by multiple signaling pathways in response to stress. Drought, salinity and cold are types of abiotic stress that lead to cellular dehydration, which causes osmotic stress. Osmotic stress also causes the production of reactive oxygen species (ROS).

Adaptation to osmotic stress is a complicated process, involving numerous changes that include decreased growth, changes in gene expression, increased levels of abscisic acid (ABA), accumulation of compatible solutes, and protective proteins, adjustment in ion transport and increases in antioxidant levels. Between various osmolytes accumulated during osmotic stress conditions, proline is the most widely studied. Proline has multifunctional roles not only functioning as a compatible osmolyte, but it can also contribute to scavenging reactive oxygen species (ROS), stabilizing subcellular structures, modulating cell redox homeostasis, supplying energy, and functioning as a signaling molecule to interact with other metabolic pathways under stress conditions. 
In higher plants, there are two pathways in proline biosynthesis using Glutamate (Glu) or Ornithine (Orn) as precursor (Figure 3). In the first pathway, Glu is phosphorylated and converted to $\Delta 1$-pyrroline-5-carboxylate (P5C) by $\Delta 1$-pyrroline-5-carboxylate synthetase (P5CS). P5C is then reduced to proline by $\Delta 1$-pyrroline-5-carboxylate reductase (P5CR). In the Orn pathway, In the second pathway, Orn is transaminated to P5C by ornithine- $\delta$ aminotransferase $(\delta$-OAT), and P5C is converted to proline by P5CR. A transcript abundance analysis in $M$. truncatula suggested that both ornithine and glutamate biosynthesis pathways contribute to the osmotic stress-induced proline accumulation (Armengaud et al., 2004). Two P5CS genes are present in Arabidopsis thaliana and also in Sorghum bicolor, and it is probable that one of them is more active under osmotic stress.

There are only a few reports showing a direct role of Pro in response to cold stress; Duncan et al. (1987) showed that exogenous proline, and inducers of proline accumulation, increase the cold tolerance of regenerable maize callus (Duncan \& Widholm, 1987). Wang et al. (2014) generated Osa-miR319b overexpressors transgenic rice lines (OE), observing a phenotype with a higher tolerance to cold stress in comparison with wild-type plants (WT). They determined the proline content of OE and WT plants under cold stress and control conditions, finding that the accumulation of PRO in OE plants was significantly higher than that in WT plants (Wang et al., 2014). The aim of this article was to find evidence of correlations between proline contents and cold tolerance in sorghum lines with contrasting tolerance and help to confirm the function of proline during the cold response in sorghum.

\section{MATERIALS AND METHODS}

\subsection{Organisms and exposure to stress}

Two genotypes of sorghum with contrasting cold tolerance were used. The R19 genotype was kindly donated by Dr. Leopoldo Mendoza Onofre from Montecillo campus of Colegio de Posgraduados, who developed this genotype from selective crosses between different sorghum lines with cold tolerance (Cisneros López et al., 2007; J Osuna-Ortega, 2003; Mendoza-Onofre et al., 2017). On the other hand, the variety TX430 is susceptible to cold and is also a genotype that has been successfully transformed (Wu et al., 2014; Wu \& Zhao, 2017). The culture of both genotypes was done during the early spring of 20016 in a substrate composed of peat moss, perlite, vermiculite $(3,1,1)$, the development of the plants was monitored until they reached the phenological phases V1, V3, V5 and HB (Vanderlip and Reeves, 1972) under semi-controlled conditions in greenhouse. Three biological replicas were used per test and two technical replicas, the plants were subjected to cold conditions $\left(5^{\circ} \mathrm{C}\right.$, for $\left.48 \mathrm{hrs}\right)$ while the same number of biological replicates were kept in the greenhouse and served as control. After exposure to cold tissues were collected and were used for the quantification of ROS and proline.

\subsection{Quantification of proline}

For the quantification of free proline in sorghum leaves, the technique described by Carillo (Carillo \& Gibon, 2011) was reproduced. Briefly, proline was extracted from leaf tissue using $90 \%$ ethanol, then reacted with an acidic solution of ninhydrin, and quantified at 520 
$\mathrm{nm}$. For each measurement, its respective calibration curve was generated with a proline standard with known concentrations of 1-0.4-0.2-0.1-0.04 mM.

\subsection{Quantification of ROS}

The technique described by Juszczak (Juszczak \& Baier, 2014), was used for ROS quantification. For this purpose, a photographic record under the same conditions of lighting and exposure was made using an SLT-A37K model camera (Sony, Japan), later the images were analyzed by the software ImageJ (National Institutes of Health, USA) to quantify the percentage of the leaf area and the intensity of spots of ROS revealed by the previous staining.

\subsection{Identification of TFBS in promoters.}

The promoter regions (1000 nucleotides of the 3' untranslated regions) of genes involved in the synthesis and degradation of proline were identified in sorghum genome (NCBI accession NZ_ABXC00000000), using the PlantTFBS program (Megraw \& Hatzigeorgiou, 2010).

\section{RESULTS}

In order to quantify the accumulation of ROS in sorghum leaves of the varieties TX430 and R19, leaves were stained with 3'-Diaminobenzidine (DAB) as described elsewhere (Jambunathan, 2010), the brown stained areas are the places where ROS accumulate. The images were taken in three biological replicas under the same conditions of staining and illumination. Figure 1 depicts specimens in the phenological phase of 5 leaves which percentage of the area with brown deposits coincides with the median of population. The lower image represents the same photograph analyzed with the ImageJ software following the technique described by Juszczak, each pixel quantified as leaf area of the leaf with DAB deposits is shown in red color, later the image was transformed to 8 bits to determine the intensity mean of the spots on a scale of 256. The rate of ROS accumulation in leaves was

calculated as the result of multiplying the percentage of leaf area by the average intensity of the spots (Fig. 1). 


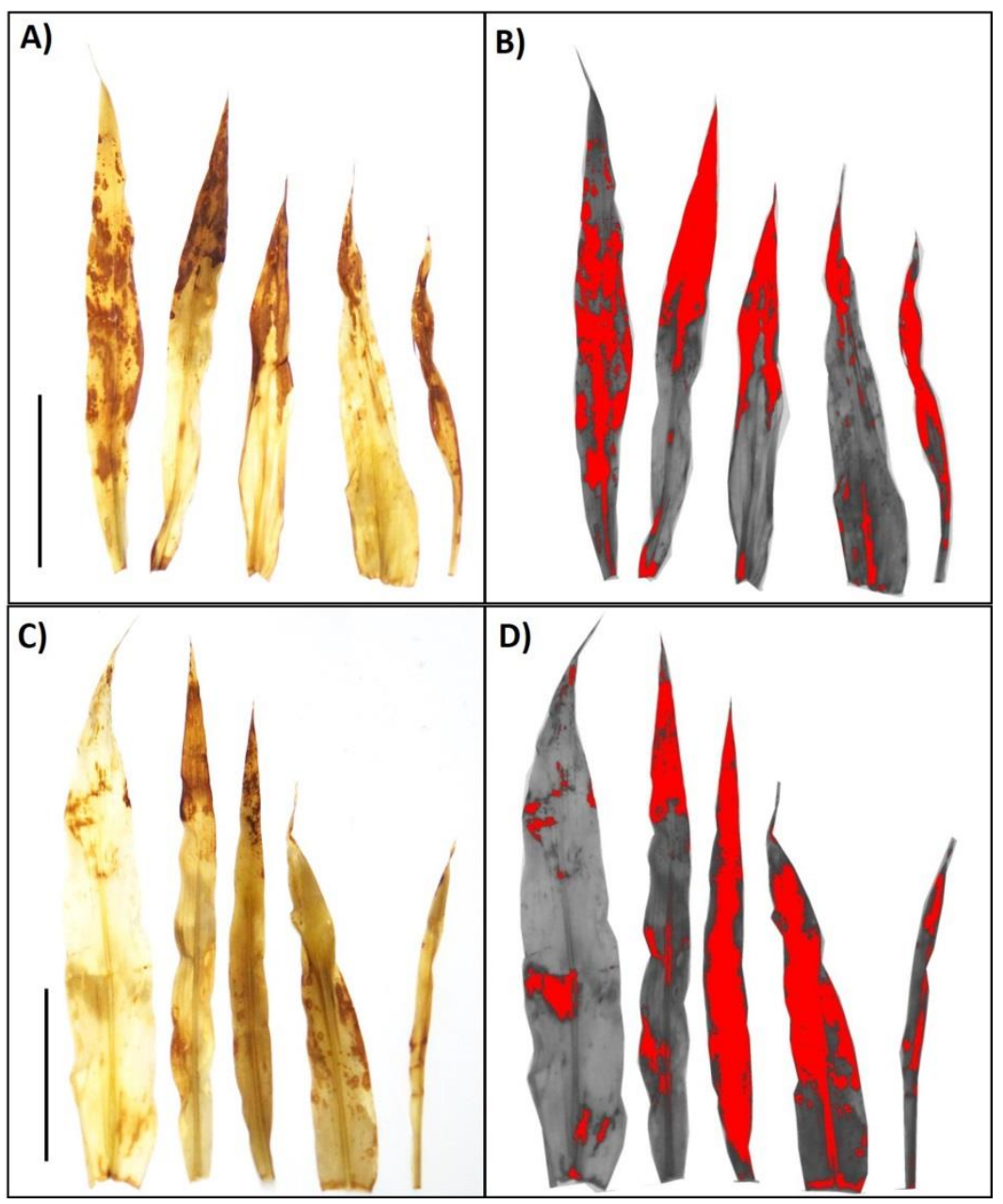

Fig. 1. ROS accumulation in leaves of sorghum after cold treatment. Leaves of the phenological phase V5 (five leaves) of sorghum were used. The brown stained areas are the places where ROS accumulate each pixel quantified as leaf area with DAB deposits is shown in red color, later the image was transformed to 8 bits to determine the intensity mean of the spots. A) Leaves of TX430 stained with DAB after cold treatment. B) ROS accumulated in leaves of TX430 using parameters described by Juszczak each pixel quantified as leaf area with $\mathrm{DAB}$ deposits is shown in red color, later the image was transformed to 8 bits to determine the intensity mean of the spots. C) Leaves of R19 stained with DAB after cold treatment. D) ROS accumulated in leaves of R19 using parameters described by Juszczak. The bar scale represents $5 \mathrm{~cm}$.

The results obtained for the accumulation of free proline in sorghum leaves at the phenological phases V1, V3, V5, and FL are shown in figure 2A. The means of free proline concentration $(\mu \mathrm{mol} / \mathrm{g}$ of fresh weight) $+/-\mathrm{SE}$ of three biological and two technical replicates are plotted. The asterisk indicates the statistically significant difference $(* \mathrm{P}$ $<0.05$ ) between varieties TX430 (susceptible to cold) and R19 (tolerant to cold) determined by a $\mathrm{T}$ student test. Figure $2 \mathrm{~B}$ shows the means of the index of the leaf area identified with ROS +/- EE. The asterisks indicate the minimum statistically significant difference (*P $<0.05$ ) between the varieties TX430 (susceptible to cold) and R19 (tolerant to cold). 
A)

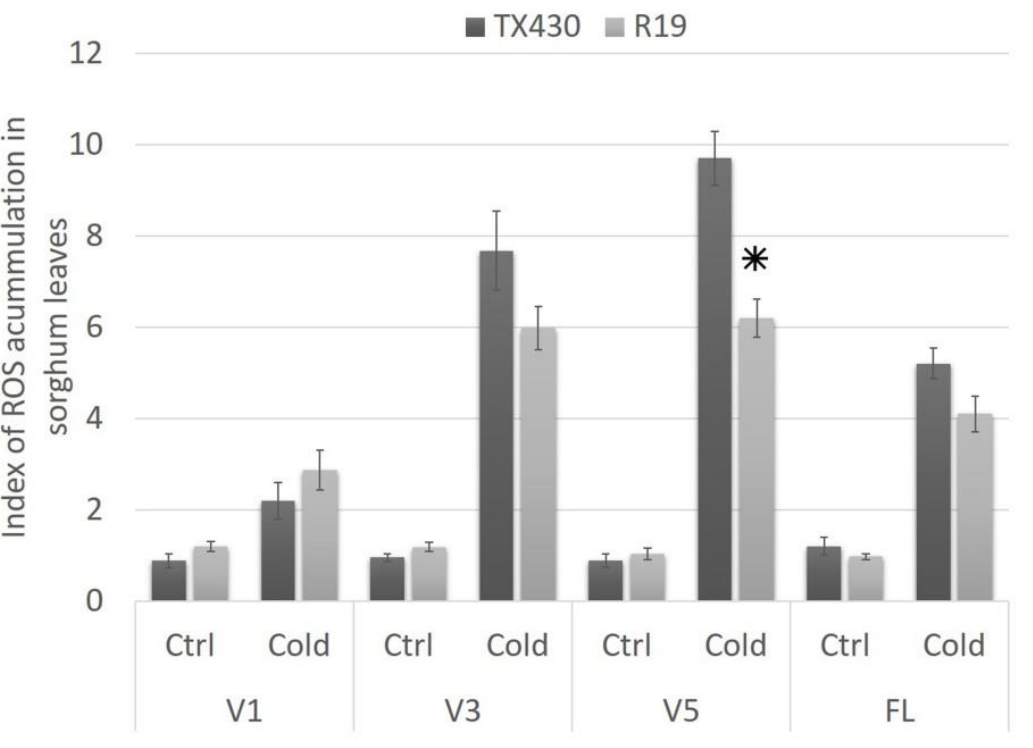

B)

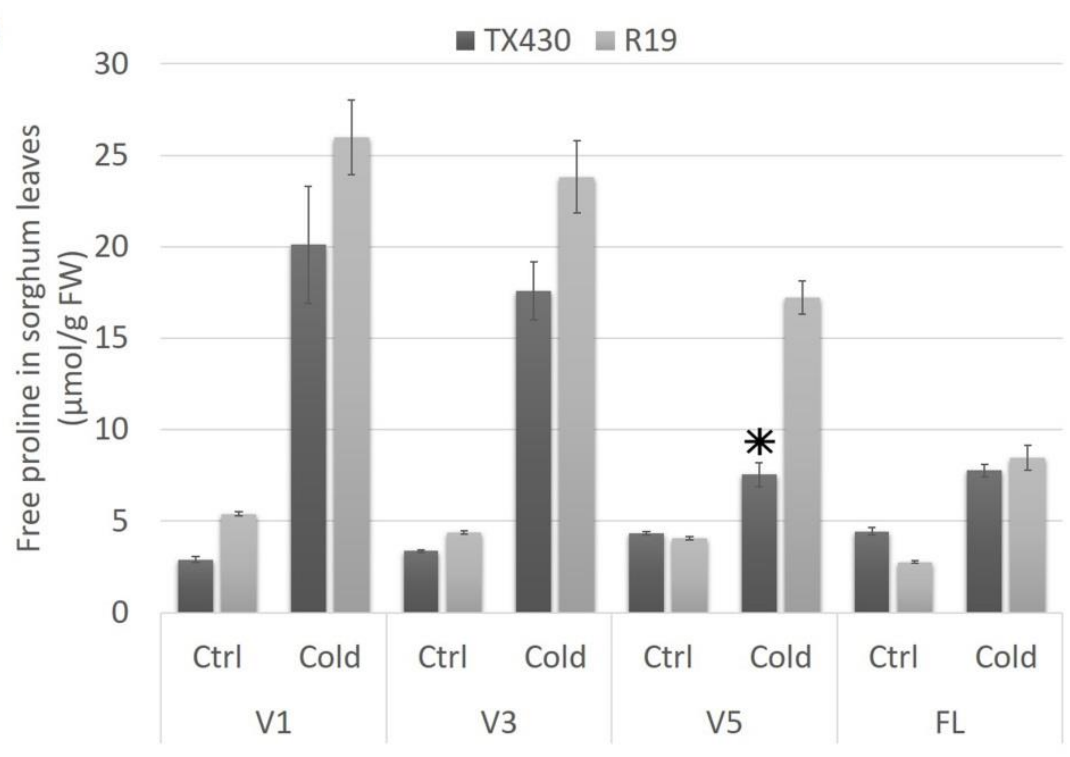

Fig. 2. Accumulation of free proline and ROS in different phenological stages of sorghum after exposure to cold treatment. A) Depicts the means of the index of the leaf area identified with ROS +/- EE. B) Means of free proline concentration ( $\mu$ mol / $\mathrm{g}$ of fresh weight) +/- SE. V1 (emergence), V3 (three leaves), V5 (five leaves) and FL (flag leaf) phenological stages of sorghum where evaluated. Three biological and two technical replicates of each variety and phenological state are plotted, the asterisks indicate the minimum statistically significant difference $(* \mathrm{P}<0.05)$ between the varieties TX430 and R19 at V5 phenological state determinated by a T student test. 
The TFBS found in the promoter regions of the genes related to proline biosynthesis and degradation are shown in Fig. 3.

A)

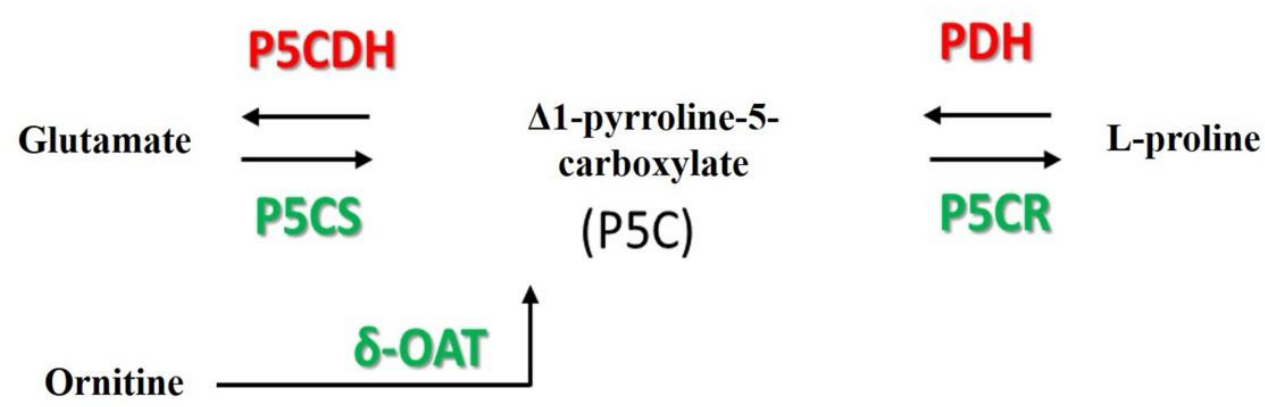

B)

\begin{tabular}{|l|l|l|l|l|l|l|l|l|l|l|l|l|l|}
\hline Gene/TFBS & a & b & c & d & e & f & g & h & i & j & k & I & m \\
\hline P5CS1 & x & $x$ & $x$ & $x$ & $x$ & $x$ & $x$ & & & & & & \\
\hline P5CS2 & & $x$ & & $x$ & $x$ & & & & & & & & \\
\hline P5CR & & $x$ & $x$ & $x$ & $x$ & $x$ & $x$ & $x$ & & & & & \\
\hline PDH & & $x$ & $x$ & $x$ & $x$ & & & & & & & $x$ & \\
\hline P5CHD & & $x$ & $x$ & $x$ & & & $x$ & & & & & $x$ & \\
\hline ठ-OAT & & & $x$ & $x$ & & & & & $x$ & $x$ & $x$ & $x$ & $x$ \\
\hline
\end{tabular}

Fig. 3. Codifying genes involved in proline biosynthesis and degradation and TFBS's found on those genes. A) Pathway of proline biosynthesis and degradation using Glutamate (Glu) or Ornithine (Orn) as precursors. Enzymes involved in biosynthesis are shown in green and enzymes involved in degradation are shown in red. B) Transcription Factor Binding Sites (TFBS) identified by bioinformatic analysis on promoters of genes involved in proline biosynthesis and degradation. a, W box; b, G box; c, ABRE; d, TATA; e, CCAAT box; f, CCAAT box; g, MBS; h, circadian; I, ARE; j, AP-2-like; k, LTR; 1, HSE and $\mathrm{m}$, Auxin response.

\section{DISCUSSION}

Previously has been reported that the phenological stages prior to the 8 leaf phase are the periods of development where sorghum is more susceptible to cold stress (Ercoli et al., 2004). Based on this, experiments were limit to an early stages study period, in addition this represents advantages to the study model, because the period for obtaining the plants is smaller, likewise, not being in a vegetative and non-reproductive period, there are fewer variables that might regulate the process of seed generation that is opposed to the assembly of responses to stress. During some vegetative phases, the proline content in response to cold stress was higher in plants of the variety R19 compared to the variety TX430 (Fig. 2). Only during the phenological phase of five leaves, a statistically significant difference was 
observed. Although in some of these phases the difference did not reach a level of statistical significance if it is considered as a biologically representative difference, that is, the difference is not noticeably higher, but it is constant. In this regard, it has been reported that the accumulation of proline in transgenic plants (Surender Reddy et al., 2015) can mitigate significantly the damage caused by salinity. Moreover, in wildtype plants, it has been observed that genotypes with a higher tolerance to drought stress accumulate a higher concentration of proline on tolerant plants compared to susceptible plants (Sivaramakrishnan et al., 1988). In contrast, reactive oxygen species accumulation was consistently higher in plants of the variety TX430 compared to the variety R19 reaching a more considerable difference in the phenological phase of five leaves. The above suggests that the R19 variety undergoes less oxidative damage when exposed to cold compared to the TX430 variety, this may be related to a higher accumulation of proline. Although the levels are not significantly different and could be related to a more complex series of regulatory processes in the plant such as the down-regulation of oxidative metabolism, the production of detoxifying enzymes such as glutathione-S transferase, the production of antioxidant metabolites that reduce the damage caused by ROS as well as the combination of some of the mentioned mechanisms.

Some of the TFBS present in the promoter regions of both isoforms of P5CS are related to osmotic stress such as the Abscisic Acid Responsive Element (ARE), this data correlates to information obtained by Armengaud (Armengaud et al., 2004) where he found these both isoforms of genes are more abundant during osmotic stress periods, on the other hand the ${ }^{\delta} \mathrm{OAT}$ promoter region contains regulatory elements essential in the regulation of the expression of during extreme conditions such as the Heat stress element (HSE) or the LowTemperature response element LTR, suggesting that the Orn pathway might be necessary for response to cold and heat stress.

\section{ACKNOWLEDGMENTS}

We thank Dr. Leopoldo Mendoza Onofre for the donation of lines tolerant to cold stress. This work was funded by The Mexican Council of Science and Technology project CB221522 and the Polytechnic Institute of Mexico project SIP20170477 and SIP20180545.

\section{CONFLICT OF INTEREST}

We declare no conflict of interest.

\section{REFERENCES}

Armengaud, P., Thiery, L., Buhot, N., Grenier-De March, G., \& Savoure, A. 2004. Transcriptional regulation of proline biosynthesis in Medicago truncatula reveals developmental and environmental specific features. Physiologia plantarum 120, 442-450.

Carillo, P., \& Gibon, Y. 2011. Protocol: Extraction and determination of proline, Australia, Prometheus Wiki, http://prometheuswiki.org/tiki-=Extractionanddeterminationofproline (accessed September 16, 2018). 
Cisneros López, M.E., Mendoza Onofre, L.E., Mora Aguilera, G., Córdova Téllez, L., \& Livera Muñoz, M. 2007. Híbridos y progenitores de sorgo tolerantes al frío. I: Calidad de la semilla y su influencia en el establecimiento de plántulas. Agrociencia 41.

Downes, R., \& Marshall, D. 1971. Low temperature induced male sterility in Sorghum bicolor. Australian Journal of Experimental Agriculture 11, 352-356.

Duncan, D.R., \& Widholm, J.M. 1987. Proline accumulation and its implication in cold tolerance of regenerable maize callus. Plant physiology 83, 703-708.

Ercoli, L., Mariotti, M., Masoni, A., \& Arduini, I. 2004. Growth responses of sorghum plants to chilling temperature and duration of exposure. European Journal of Agronomy 21, 93-103.

Jambunathan, N. 2010. Determination and detection of reactive oxygen species (ROS), lipid peroxidation, and electrolyte leakage in plants. Methods of Molecular Biology 639, 292-298.

Juszczak, I., \& Baier, M. 2014. Quantification of superoxide and hydrogen peroxide in leaves. Plant Cold Acclimation: Methods and Protocols, 217-224.

McLaren, N., \& Wehner, F. 1992. Pre-flowering low temperature predisposition of sorghum to sugary disease Claviceps africana. Journal of Phytopathology 135, 328-334.

Megraw, M., \& Hatzigeorgiou, A.G. 2010. MicroRNA promoter analysis. Methods in Molecular Biology 592, 149-161.

Mendoza-Onofre, L.E., Cisneros-López, M.E., Galicia-Juárez, M., \& Hernández-Martínez, M. 2017. Líneas mantenedoras (Líneas B) y restauradoras (Líneas R) de sorgo granífero adaptadas a los valles altos centrales de México. Revista Fitotecnia Mexicana 40, 107-110.

Osuna-Ortega, J., \& Mendoza-Onofre L.E. 2003. Sorghum cold tolerance, pollen, production, and seed yield in the central High Valleys of Mexico. Maydica 48, 125132.Singh, S.P. 1985. Sources of cold tolerance in grain sorghum. Canadian journal of Plant Science 65, 251-257.

Sivaramakrishnan, S., Patell, V.Z., Flower, D., \& Peacock, J. 1988. Proline accumulation and nitrate reductase activity in contrasting sorghum lines during mid-season drought stress. Physiologia Plantarum 74, 418-426.

Surender Reddy, P., Jogeswar, G., Rasineni, G.K., Maheswari, M., Reddy, A.R., Varshney, R.K., and Kavi Kishor, P.B. 2015. Proline over-accumulation alleviates salt stress and protects photosynthetic and antioxidant enzyme activities in transgenic sorghum [Sorghum bicolor (L.) Moench]. Plant physiology and biochemistry : PPB / Societe francaise de physiologie vegetale 94, 104-113. 
Tiryaki, I., \& Andrews, D.J. 2001. Germination and seedling cold tolerance in sorghum. Agronomy Journal 93, 1391-1397.

Vanderlip, R., \& Reeves, H. 1972. Growth stages of sorghum [Sorghum bicolor,(L.) Moench.]. Agronomy Journal 64, 13-16.

Wang, S.T., Sun, X.L., Hoshino, Y., Yu, Y., Jia, B., Sun, Z.W., Sun, M.Z., Duan, X.B., \& Zhu, Y.M. 2014. MicroRNA319 positively regulates cold tolerance by targeting OsPCF6 and OsTCP21 in rice (Oryza sativa L.). PloS one 9, e91357.

Wu, E., Lenderts, B., Glassman, K., Berezowska-Kaniewska, M., Christensen, H., Asmus, T., Zhen, S., Chu, U., Cho, M.J., \& Zhao, Z.Y. 2014. Optimized -mediated sorghum transformation protocol and molecular data of transgenic sorghum plants. In vitro cellular $\&$ developmental biology Plant : Journal of the Tissue Culture Association 50, 9-18.

Wu, E., \& Zhao, Z.Y. 2017. Agrobacterium-Mediated Sorghum Transformation. Methods in Molecular Biology 1669, 355-364. 